\title{
Development of Immunity to Ostertagia ostertagi (Trichostrongylidae: Nematoda) in Pastured Young Cattle
}

\author{
By J. Grønvold, P. Nansen, L. C. Gasbarre, C. M. Christensen, M. Larsen, J. Monrad and \\ N. Midtgaard \\ Department of Veterinary Microbiology, Royal Veterinary and Agricultural University, Frederiksberg, \\ Denmark, and Helmintic Diseases Laboratory, Agricultural Research Service, United States Department of \\ Agriculture, Beltsville, Maryland, U.S.A.
}

\begin{abstract}
Grønvold,J., P.Nansen, L.C.Gasbarre, C.M.Christensen, M.Larsen, J.Monrad and N.Midtgaard: Development of immunity to Ostertagia ostertagi (Trichostrongylidae: Nematoda) in pastured young cattle. Acta vet. scand. 1992, 33, 305-316. - This experiment comprised 3 groups of calves, $(+\mathrm{P} 2),(-\mathrm{P} 2)$ and $(-\mathrm{P} 1)$, which all started their first grazing season as parasite-free calves. The (+P2)- and (-P2)-group grazed 2 seasons. In the first season the (-P2)-group of calves was grazing a pasture with no detectable trichostrongyles and treated with anthelmintics every second week. The untreated $(+\mathrm{P} 2)$-group grazed an Ostertagia ostertagi contaminated pasture. During the second grazing season these 2 original groups grazed together with a new group of first-year grazing calves (-P1) on paddocks infected with $O$.ostertagi.

Parasitological analyses showed that $(+\mathrm{P} 2)$-group had negligible egg excretions in the second year in comparison with (-P2) and (-P1). This indicated, that the egg output may be regulated through acquired immunity. The difference in egg excretions was not reflected in the serum pepsinogen levels, which were only slightly elevated for all groups in the second year. Post mortem examination at the end of the experiment showed that only the (-P1)-group harboured relatively high numbers of worms in the abomasa at that time.

Antibodies of 3 immunoglobulin classes were investigated: IgA, IgG1 and IgG2. The $\operatorname{IgA}$ and IgG1 responses correlated with the presence of developing and adult worms in the abomasa and they remained elevated in the (+P2)-group throughout the experiment, perhaps indicating an involvement of these antibodies in a protective immune response. In the (-P2)-group the $\mathrm{IgA}$ and $\mathrm{IgG} 1$ showed fast and sharp rises during the second season that most likely were age-related and as such a result of maturation of the immune system. The role of $\mathrm{IgG} 2$ is unclear as the IgG2 response was weak in all groups of calves and difficult to relate to the parasitological data.
\end{abstract}

nematodes; endoparasites.

\section{Introduction}

For many years ostertagiasis has been regarded as a problem almost exclusively confined to animals in their first grazing season. In contrast, ostertagiasis in older age groups, such as second season heifers, generally shows much less impact in terms of low parasite egg output and rare occurrence of clinical disease. Striking differences in this respect between first and second season ani- 
mals, have recently been documented in field situations in Holland (Ploeger 1989) and Denmark (Nansen et al. 1990).

Evidence from experimental studies and from field observations suggests that the immunity exhibited by animals in their second and subsequent grazing seasons is predominantly due to previous antigenic stimulation from infection with Ostertagia ostertagi (e.g. reviews by Armour 1970, Armour \& Ogbourne 1982, Klesius 1988, Armour 1989). Literature is rather replete with regard to existence of age resistance per se, but some studies strongly suggest that this only plays a minor role, if any (Baily \& Herlich 1953, Herlich 1960, Michel et al. 1979). Yet, older animals may be more resistant to the debilitating effects of ostertagiasis (Herlich 1960, 1980 ), and may to some extent influence the course of infection by slowing down worm development and egg production (Armour 1967). Experimentally, it has been shown that older animals have an increased ability to acquire immunity (Michel et al. 1979), but this has not been documented in the field situation.

For obvious reasons, control of ostertagiasis has mainly been applied to first season calves. This has been attempted in a number of ways, but over the last decade, control by strategic chemotherapy has, in particular, led to great achievements. However, the advent of chemoprophylactic measures of high efficacy raises the question of whether calves so protected are sufficiently exposed to stimulate immunity, and strategies that greatly reduce parasite transmission in first season calves have been shown to delay the onset of immunity to $O$. ostertagi to an extent that may have negative consequences for the second season (Armour et al. 1988, Ploeger 1989).

For this and other reasons, there is a contin- ued need to study the immunity naturally acquired during the course of the field situation and, furthermore, to investigate how immunity is influenced by age. The present experiment, conducted over 2 consecutive grazing seasons on pastures originally seeded with a monoculture of $O$. ostertagi, was designed to evaluate how immunity develops as a result of parasite infection in different age-groups of calves.

\section{Materials and methods}

Experimental design

Grazing 1988. Twenty initially parasitefree Jersey bullocks, 5 to 6 months old and weighing between 86 and $186 \mathrm{~kg}$, were pastured in 1988. The calves were divided into 2 groups of 10 animals with approximately the same average weight of $140 \mathrm{~kg}$, and subsequently turned out on each of 2 paddocks on the 18th of May 1988. One group designated $(+\mathrm{P} 2)$, i.e. becoming infected with parasites $("+\mathrm{P}$ ") in their first grazing season, was grazing a paddock designated $(+)$, contaminated with a Danish strain of $O$. ostertagi. The other group designated (-P2), i.e. not becoming infected with parasites ("-P") in their first grazing season, was turned out on a paddock designated (-). No detectable trichostrongyles were present on the (-)-paddock at the start of the experiment. The distance between the 2 paddocks was a few hundred meters. Attempts were made to prevent any build up of parasites in calves on the (-)-paddock by giving treatments with albendazole (Valbazen ${ }^{\mathrm{R}}$ ) every second week during the grazing season. The $(+\mathrm{P} 2)$-group of calves on the other paddock was treated twice with albendazole $\left(\right.$ Valbazen $^{\mathrm{R}}$ ) on the 27th of July and again on the 7th of September 1988 because the animals suffered from clinical ostertagiasis. During the later part of the grazing period both groups were offered sup- 
plementary feed in the form of hay and concentrate. One calf from the (+P2)-group suffered from a severe broncho-pneumonia and it finally was slaughtered in July 1988.

Stabling period $1988 / 1989$. Both groups were housed on the 5th of October 1988, and on this occasion the calves in the (-P2)-group were treated with a single therapeutic dose of ivermectin $\left(\right.$ Ivomec $^{R}$ ) to ensure that all animals in this group did not harbour worms in the winter. At the same time one calf from the (+P2)-group and 2 calves from the (-P2)group were slaughtered. The groups now contained 8 calves each, but unfortunately 1 calf from the (-P2)-group had to be slaughtered just after housing suffering from an abdominal hernia.

Grazing 1989. The (+P2)- and (-P2)-group were now second season grazing calves, as symbolized by " 2 ". These 2 original groups were turned out to graze together with a new group of 65 to 6 months old parasite-free Jersey bullocks on the 27th of April 1989. The group of new calves was designated (-P1), i.e. initially parasite-free (“-P”) and first-season grazing animals, which grazed only 1 season (" 1 "). The calves in the (-P1)group had a body weight between 118 and $156 \mathrm{~kg}$, with an average of $140 \mathrm{~kg}$. At turnout, 2 calves from the $(+\mathrm{P} 2)$ - and 1 from the (-P2)-group were slaughtered, leaving 6 calves in each of the 3 groups: (+P2), (-P2) and (-P1). The 3 groups grazed together in 1 herd and no anthelmintic treatments were given during this period. The calves started grazing on the infected (+)-paddock. After 2 weeks on this paddock they were moved to the (-)-paddock, because of reduced forage. Every second week the calves changed paddock. The period from June to August 1989 was very dry and grass became scarce on both paddocks. During this period the calves were offered supplementary hay and concentrate. Two calves from each group were slaughtered at the end of the experiment on the 5th of October 1989.

\section{Parasitological analyses}

Blood and faecal samples were taken from the calves at approximately 2 -week intervals. Blood samples were analyzed for serum pepsinogen, which reflects the pathogenic effect of $O$. ostertagi, according to a procedure used by Ross et al. (1967). Faecal egg counts were made according to a modified McMaster technique described by Henriksen \& Aagaard (1976). The abomasa from the slaughtered calves were eviscerated and examined to assess the worm burdens according to the procedure described by Grønvold et al. (1989).

During the grazing seasons samples of herbage were collected every second week. A herbage sample constituted approximately $200 \mathrm{~g}$ of grass picked by hand at intervals of 5 steps, following a W-shaped route across the paddock. The number of infective trichostrongyle larvae were determined by the agar technique (Jørgensen 1975, Mwegoha \& Jørgensen 1977).

\section{Immunological analyses}

Serum from the calves were analyzed for antibodies against O.ostertagi antigens by an enzyme linked immunosorbent assay (ELISA) according to the method described by Canals \& Gasbarre (1990). The antigens used were crude whole worm extracts of O.ostertagi prepared from 4th moult larvae, which were recovered from the abomasa of experimentally infected animals as described by Canals \& Gasbarre (1989). Antibodies of 3 isotypes were determined, namely $\operatorname{IgA}, \mathrm{IgG} 1$ and IgG2. 


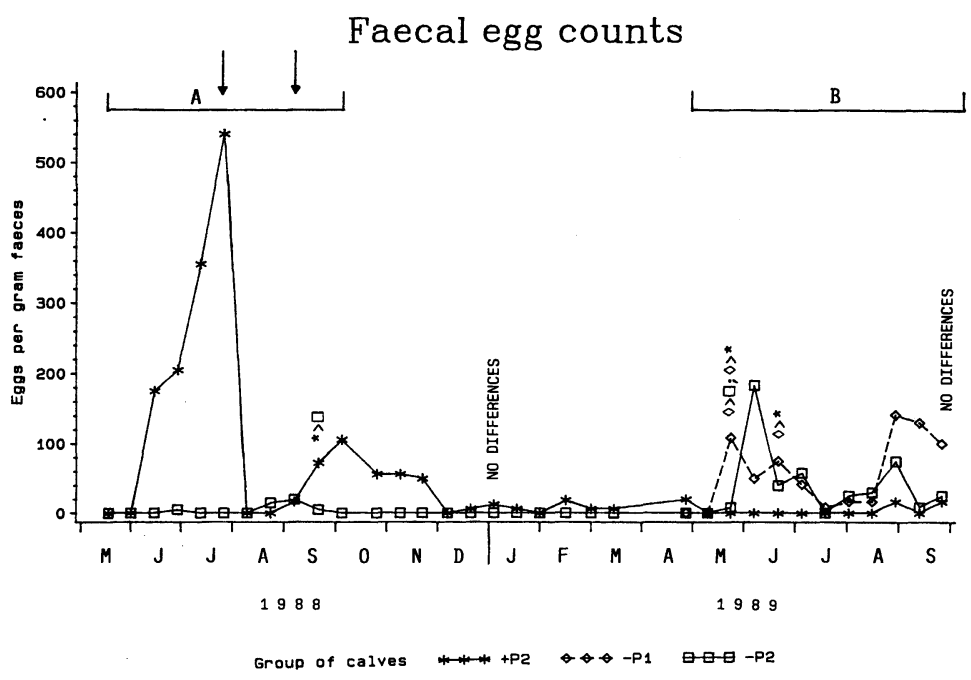

Figure 1. The average number of parasite eggs per gram faeces from the groups of experimental calves. Legend: The (+P2)-group of calves was infected with parasites in their first-grazing season (A) in 1988. In the first season (A) in 1988 the (-P2)-group of calves was grazing a pasture with no detectable trichostrongyles at the start of the experiment and treated with anthelmintics every second week. In their second grazing season (B) in 1989 these 2 original groups grazed together with young first-season grazing calves called the (-P1)group on infected paddocks. The arrows indicate the 2 treatments of the (+P2)-groups with albendazole in 1988. Results from the statistical analysis are shown on the figure.

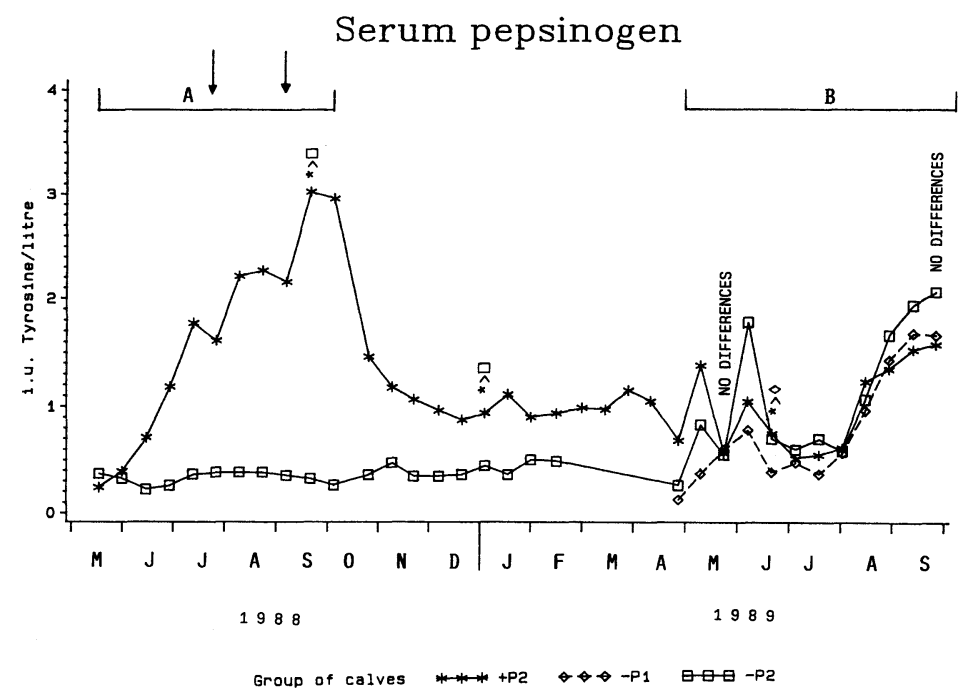

Figure 2. The average serum pepsinogen level (i.u. Tyrosine per litre) in serum from the groups of experimental calves. For legend to figure, see Fig. 1. 


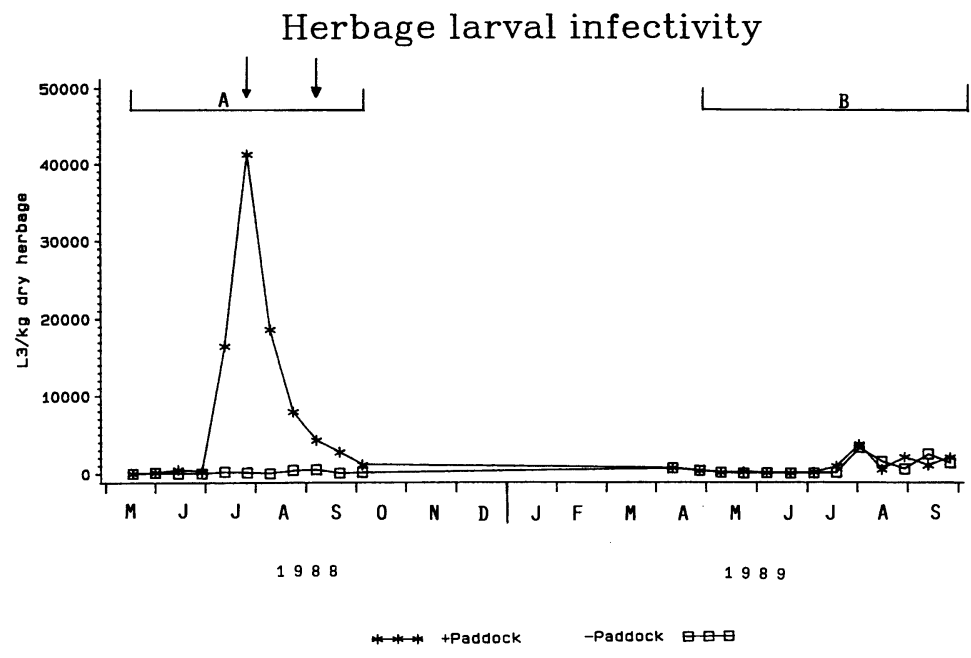

Figure 3. Concentration of infective parasite larvae per kg dry herbage from the 2 experimental paddocks. $\left(^{*}\right)$ is the (+)-paddock grazed by the infected group of calves $(+P 2)$ in 1988. ( $\left.\square\right)$ is the (-)-paddock grazed by the non- or low-infected group (-P2) in 1988. In the grazing season 1989 all groups grazed together, changing between the (+)- and the (-)-paddock every second week. For legend to figure, see Fig. 1.

\section{Statistical analyses}

Differences between groups were analyzed at the following times: near the end of the first grazing season (21st of September 1988); in the middle of the housing period (4th of January 1989); one month after turnout the second year (24th of May 1989); two months after turnout (21st of June 1989); and at the end of the second grazing season (26th of September 1989). General Linear Models (GLM) procedures were used to assess the differences between the treatment groups (+P2),(-P2) and (-P1), with the $\mathrm{p}<0.05$ being considered significant. Whenever assumptions of the GLM procedure were not met, data were ranked and non-parameter analyses were performed. When significant treatment effects were noted, multiple comparisons of the 3 treatments were performed with a Sidak T test (Gaines 1977), and a $\mathrm{p}$ value $<0.017$ was considered significant.

\section{Results}

Parasitological findings

Grazing 1988. The (+P2)-group grazing the contaminated (+)-paddock, became infected with $O$. ostertagi resulting in high egg outputs in June and July (Fig. 1), and the animals in this group became clinically affected in the second half of the grazing period in 1988, as further reflected in high serum pepsinogen levels (Fig. 2). The infection level of the (-P2)-calves was very low, as judged from the negligible egg excretion, (Fig. 1), and the serum pepsinogen levels, (Fig. 2). The difference in egg output was in accordance with the difference in herbage larval infectivity between the 2 experimental paddocks (Fig. 3). Results from worm burden determinations of the calves after the first grazing season, confirmed that only the $(+\mathrm{P} 2)$-group was severely infected by $O$. ostertagi (Table 1). At the end of the first 
Table 1. Adults and larvae of Ostertagia ostertagi in the abomasa from the slaughtered calves. (The 3 groups of calves (+P2), (-P2) and (-P1) are described in Fig. 1.)

\begin{tabular}{|c|c|c|c|c|c|c|}
\hline \multirow{2}{*}{$\begin{array}{l}\text { Time of } \\
\text { slaughter }\end{array}$} & \multicolumn{2}{|c|}{$+\mathrm{P} 2$} & \multicolumn{2}{|c|}{$-\mathrm{P} 2$} & \multicolumn{2}{|c|}{$-\mathrm{P} 1$} \\
\hline & Adults & Larvae & Adults & Larvae & $\overline{\text { Adults }}$ & Larvae \\
\hline $5-10-1988$ & 52,430 & 242,530 & 0 & 20 & - & - \\
\hline $\begin{array}{l}\text { At the end of the first } \\
\text { grazing season }\end{array}$ & * & * & 0 & 0 & - & - \\
\hline 2-05-1989 & 10 & 0 & 10 & 0 & - & - \\
\hline $\begin{array}{l}\text { At the beginning of } \\
\text { the second grazing season }\end{array}$ & 0 & 0 & ** & $* *$ & - & - \\
\hline $5-10-1989$ & 0 & 340 & 120 & 14,600 & 5,650 & 84,380 \\
\hline $\begin{array}{l}\text { At the end of the second } \\
\text { grazing season }\end{array}$ & 0 & 190 & 0 & 30 & 4,111 & 87,520 \\
\hline
\end{tabular}

*) This calf contained 41,620 adults and 9,280 larvae at the time of slaughter on the 27th of July 1988.

**) This calf contained 0 adults and 0 larvae at the time of slaughter on the 14 th of October 1988.

grazing season the (+P2)-group had a significantly higher egg excretion and pepsinogen level.

Stabling period $1988 / 1989$. As seen in Table 1, worm burdens in the (+P2)-group of calves were lost in the course of the preceding housing period. No signs of Type II ostertagiasis were observed during that time although the serum pepsinogen levels remained significantly elevated (Fig. 2).

Grazing 1989. Throughout the summer of 1989 , all the calves alternately grazed the $(+)$ - and the (-)-paddock, and as could be expected both paddocks were reinfected by O.ostertagi (Fig. 3).

After turnout in 1989 only the (-P2) and the (-P1)-groups, which had previously been exposed to no or at least extremely few parasitic nematodes, excreted appreciable numbers of eggs (Fig. 1). Levels of egg output from both groups were comparable. In contrast, the previously exposed (+P2)-group excreted negligible numbers of eggs throughout the 1989 season, indicating that egg excretion may be regulated by acquired immunity (Fig. 1). Two months after turnout the (-P1)-calves excreted significantly more eggs than the $(+\mathrm{P} 2)$-calves, and the (-P2)calves were intermediate between the two groups.

The differences in egg excretions were not reflected in the serum pepsinogen levels, which were slightly elevated in all groups towards the end of the second grazing season in 1989 (Fig. 2) indicating that all animals had been exposed to a low O.ostertagi larval population on herbage. In 1989 significant differences in serum pepsinogen values were only detected on the 21 st of June. At this time the (+P2)-group was significantly higher than the (-P1)-group, and the (-P2)-group was intermediate.

The (-P1)-group of calves harboured a relatively high number of worms, mainly larvae, in the abomasa at the end of the grazing season of 1989. Worm burdens in the abomasa of the 2 other groups $((-\mathrm{P} 2)$ and $(+\mathrm{P} 2))$ were low (Table 1). This may indicate that a certain level of age-related immunity developed in the (-P2)-group. 


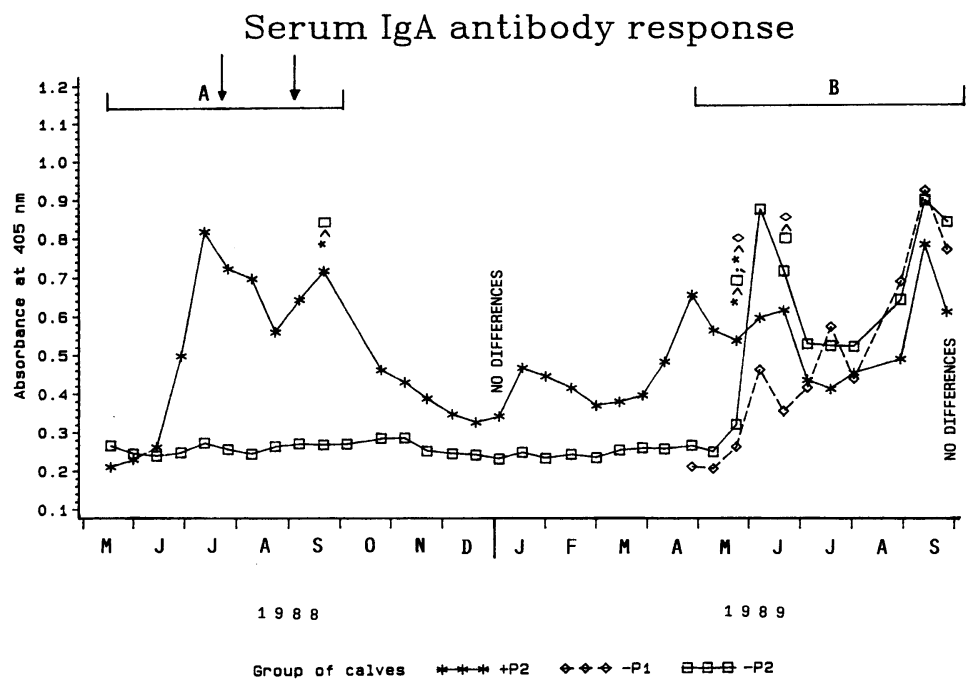

Figure 4. Serum IgA levels of the experimental calves. The results are expressed as mean absorbance values at $405 \mathrm{~nm}$ for each group. For legend to figure, see Fig. 1.

At the end of the experiment it was found that approximately $40 \%$ of the larvae on herbage at that time were Cooperia spp. The source of this contamination is unknown, but apparently it arose during the grazing period in 1989.

\section{Immunological findings}

The results indicate that exposure to O.ostertagi induced serum antibody responses in all of the 3 immunoglobulin classes investigated.

IgA: The (+P2)-group showed a rise in $\operatorname{IgA}$ antibody levels in 1988 with peak levels in July, 6-8 weeks after turnout on pasture, and again in September, (Fig. 4). The antibody levels of the $(+\mathrm{P} 2)$-group decreased during the winter housing period, and at this time were not significantly different from the level found in the (-P2)-group. Initially in 1989, the (+P2)-group had significantly higher $\operatorname{IgA}$ antibody responses than the 2 other groups.
However, 6 weeks after turnout the (-P2)group showed a sharp rise in $\operatorname{IgA}$ antibody response, whereafter the $(+\mathrm{P} 2)$ - and the (-P2)-group had similar IgA antibody levels (Fig. 4). The IgA response following turnout was relatively low for the first-season grazing (-P1)-group when compared to the older $(+\mathrm{P} 2)$ - and (-P2)-groups, but reached equally high levels late in the grazing season.

IgG1: The (+P2)-group exhibited a continuous rise in IgG1-serum levels during the 1988 season, with responses reaching a peak around the time of housing (Fig. 5), wheras no, or at least only a weak, IgG1 antibody response was detected in the (-P2)-calves. During the housing period the IgG1 antibody level of the (+P2)-group dropped somewhat, but remained significantly elevated. The antibody levels in the $(+\mathrm{P} 2)$-group started to rise again upon turnout on pasture the second year. Some weeks later the (-P2)-animals 


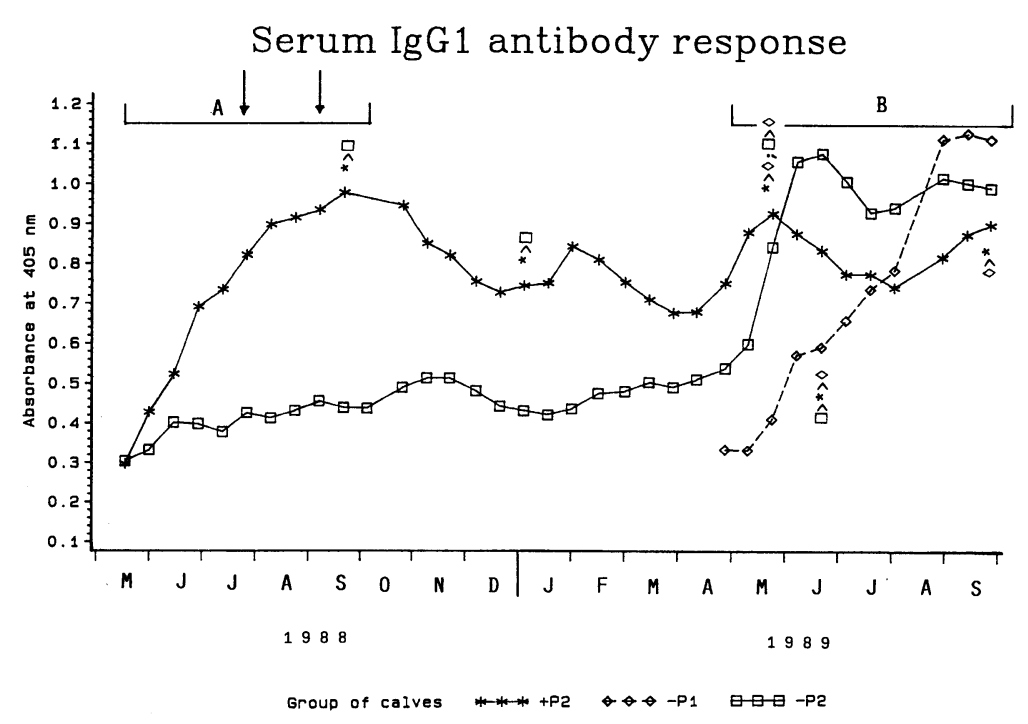

Figure 5. Serum IgG1 levels of the experimental calves. The results are expressed as mean absorbance values at $405 \mathrm{~nm}$ for each group. For legend to figure, see Fig. 1.

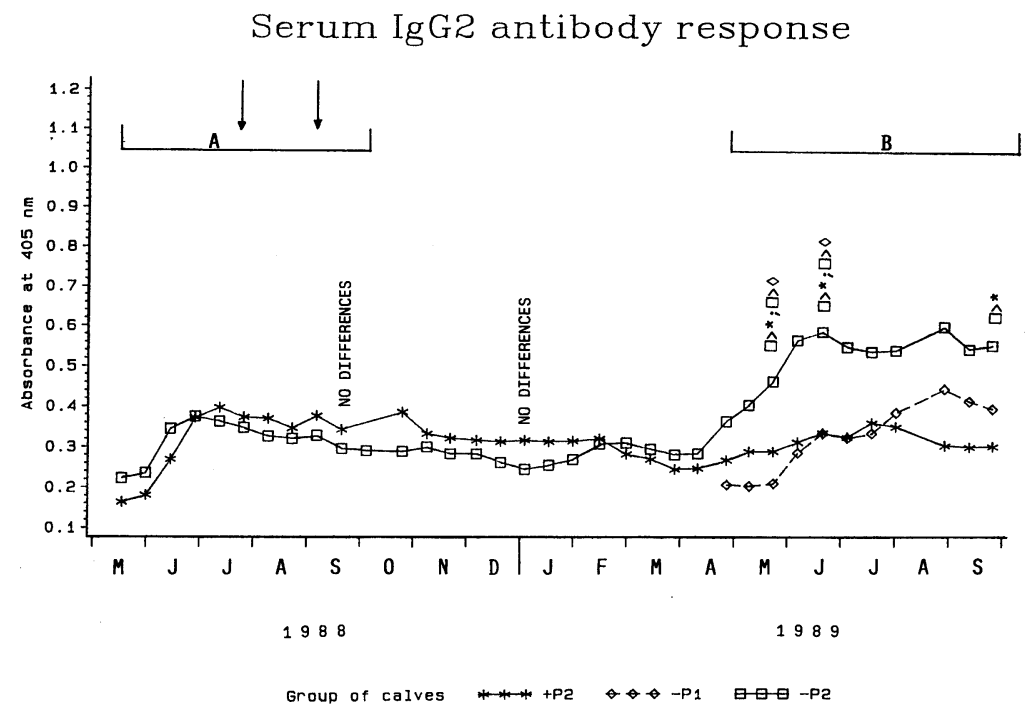

Figure 6. Serum IgG2 levels of the experimental calves. The results are expressed as mean absorbance values at $405 \mathrm{~nm}$ for each group. For legend to figure, see Fig. 1. 
showed a sharp rise in IgG1-levels with a peak occurring 6-8 weeks after turnout, and the response remained elevated throughout the experiment (Fig. 5). In the (-P1)-group, the IgG1 response continued to rise slowly in a manner similar to that of the $(+\mathrm{P} 2)$-group in the first season.

IgG2: Finally, the IgG2 antibody responses seen for both the $(+\mathrm{P} 2)$ - and the (-P2)-group pastured during the first year showed moderate rises that remained at fairly constant levels and without significant differences between the groups until the turnout on pasture the second year (Fig. 6). During the 1989-grazing season IgG2 antibody response of the (-P2)-group rose to peak levels 6-8 weeks after pasturing, and remained elevated until the end of the experiment (Fig. 6). This group had significantly higher IgG2 responses in May and June 1989 when compared to the (+P2)-group, which showed no change in IgG2 levels (Fig. 6). A slight increase in the IgG2 antibody response was discernible in the (-P1)-group by the end of the grazing season in 1989 (Fig. 6).

\section{Discussion}

This experiment was designed to investigate the influence of previous infection and age on development of immunity in calves to $O$. ostertagi under field conditions.

At the beginning of the second grazing season in 1989, the (-P2)-group had egg excretions comparable to those of the young susceptible calves (-P1). Thus, although the (-P2) animals had apparently been exposed to parasite antigens in their first grazing season, they were not rendered resistant to reinfection. The decreased egg output from group (-P2) at the end of the grazing season, 1989 is in accordance with the finding that the (-P2)-calves harboured only few adults and larvae of O.ostertagi in the abomasum at the time of slaughter in 1989. The faster parasitological response in the (-P2)-group in 1989 most likely indicate a maturation of the immune system by age as compared to the young first season grazers in group (-P1). The $(+\mathrm{P} 2)$-calves seemed to have acquired immunity to O.ostertagi in the course of their first heavily exposed grazing season, as the faecal egg counts were very low and no adult worms and very few larvae were recovered from the abomasa after the second season.

Although Cooperia spp. larvae were found on the herbage at the end of the experiment in 1989, the presence of several thousand adults and larvae of $O$.ostertagi in the susceptible (-P1)-animals showed that O.ostertagi was an essential part of the infection. Therefore, we consider the conclusions on the depression of egg excretion in previously infected second-year grazers as valid for O.ostertagi.

The IgA class of antibodies is excreted to the surface of the gastrointestinal mucosa and may be directly related to infections with gastrointestinal nematodes. This is in accordance with the finding that the IgA responses followed the rise in serum pepsinogen levels and faecal egg counts. Moreover it seems to be confirmed by the drop in serum-IgA antibody levels following anthelmintic drug treatments in the $(+\mathrm{P} 2)$-group. The steep rise of $\operatorname{IgA}$ in the (-P2)-group in May and June 1989 may be due to priming of the immune apparatus by the low infection in 1988 , but most likely it is a result of development of the immune system caused by age.

IgG1 may be produced as a result of inflamation e.g. caused by O.ostertagi larvae developing in the abomasal glands, which is consistent with the pattern shown in Fig. 5. The IgG1 level was significantly elevated in the (+P2)-group from autumn the first season 
and onwards until the end of the experiment. The sharp rise in IgG1 in the (-P2)-group in May 1989 is most likely age-related resulting in a fast response to infections.

During the first grazing season the IgG2 responses were insignificant and could not be correlated to a build-up of immunity. In the course of the second grazing season in 1989, the IgG2 antibody response of group (-P2) was significantly faster and stronger than that of the 2 other experimental groups. This is in agreement with results obtained by Gasbarre (1991), who found that drug attenuation of O.ostertagi infected calves enhanced serum IgG2 responses. However, no explanation can be forwarded with regards to the lacking IgG2 responsiveness of the (+P2)-group. According to Gasbarre \& Canals (1989) a rise in the specific IgG2 response appears, at least for experimental infections with Oesophagostomum radiatum, to correlate with the occurrence of a protective immunity. The positive secondary humoral immune response of the immunoglobulin classes investigated, do not necessarily imply that the (-P2)-calves had acquired immunity during the first grazing season, but it is rather a manifestation of maturation of their immune system possibly combined with a moderate priming of the system. Both maturation of the immune system and priming may enable the animals to launch a faster secondary response as seen in this experiment.

First season grazing young calves are most vulnerable to infections with O.ostertagi and other trichostrongyles, and as a result of exposure to parasites they slowly acquire immunity. It appears that previous experience of a patent infection is necessary to inhibit the development of O.ostertagi, as proposed by Michel et al. (1973). Whether the IgA, IgG1 or other immunoglobulins are involved in immunity to O.ostertagi remains to be elucidated. However results from the present field experiment have indicated that older susceptible animals acquire immunity faster than young susceptible calves.

The present experiment has confirmed that cattle only pass insignificant numbers of parasite eggs in the faeces in their second grazing season provided that they have been exposed in their first season. The practical implementation of this phenomenon for controlling trichostrongylosis has been described by Nansen et al. (1990) who showed that first-season grazing calves benefit from mixed grazing with older immunized animals, showing less parasitism and higher performance, most likely because the pasture is less contaminated per unit area due to the very low egg deposition of the older animals. The idea is to "dilute" the susceptible animals by older immunized animals, resulting in a low average worm egg contamination of the pasture. However this beneficial effect would presumably not have been obtained if the older animals had not been exposed to infection in a previous season.

\section{Acknowledgements}

We wish to express our gratitude to Dr. A. Guidry, Milk Secretion and Mastitis Laboratory, Beltsville, MD for providing rabbit anti-bovine IgA, IgG1 and IgG2. Our thanks are also due to Dr. Peter Lind and Dr. Henrik Bjørn for useful suggestions concerning the manuscript. This study was supported by the Danish Agricultural and Veterinary Research Council, grant no. 13-4292-2.

\section{References}

Armour J: Ostertagia ostertagi infections in the bovine: Field and experimental studies. Ph.D. Thesis, University of Glasgow, Scotland. 1967.

Armour J: Immunity to gastro-intestinal nematodes, with particular reference to cattle. In Practice. A Merck Sharp \& Dohme Technical Publication. 1970 , no. 6 . 
Armour J: The influence of host immunity on the epidemiology of trichostrongyle infections in cattle. Vet. Parasit. 1989, 32, 5-19.

Armour J, Bairden K, Ryan WG: Immunity of ivermectin treated cattle to challenge from helminth parasites in the following season. Vet. Rec. 1988, 122, 223-225.

Armour J, Ogbourne CP: Bovine Ostertagiasis: A review and annotated bibliography. Commonwealth Agricultural Bureaux, England. 1982, 93 pp.

Baily WS, Herlich H: An epizootic of gastroenteritis in mature cattle. Auburn Veterinarian. 1953, 9, 105-110.

Canals A, Gasbarre LC: Procedure for the recovery of excretory-secretory products from moulting fourth-stage larvae of Ostertagia ostertagi. Proc. Helminth. Soc. of Washington. 1989, 56, 201203.

Canals A, Gasbarre LC: Ostertagia ostertagi: Isolation and partial characterization of somatic and metabolic antigens. Int. J. Parasit. 1990, 20, 1047-1054.

Gaines PA: An improved T-table for simultaneous control on $\mathrm{g}$ contrasts. J. Amer. stat. Assoc. $1977,72,531-534$.

Gasbarre LC: Immunity to Ostertagia ostertagi: Humoral and cellular immune responses associated with regulation of parasite numbers and fecundity. Vet. Parasit. (submitted).

Gasbarre LC, Canals A: Induction of protective immunity in calves immunized with adult Oesophagostomum radiatum somatic antigens. Vet. Parasit. 1989, 34, 223-238.

Grønvold J, Henriksen SA, Nansen P, Wolstrup J, Thylin J: Attempts to control infection with Ostertagia ostertagi (Trichostrongylidae) in grazing calves by adding mycelium of the nematode-trapping fungus Arthrobotrys oligospora (Hyphomycetales) to cow pats. J. Helminth. 1989, 63, 115-126.

Henriksen SvAa, Aagaard K: En enkel flotationsog McMastermetode. (A simple flotation and McMaster method). Nord. Vet.-Med. 1976, 28, 392-397.

Herlich H: Age resistance of cattle to nematodes of the gastrointestinal tract. J. Parasit. 1960, 46, 392-397.

Herlich H: Ostertagia ostertagi infection and reinfection in cattle of different ages. Amer. J. vet. Res. 1980, 41, 259-261.

Jørgensen RJ: In vitro migration of Dictyocaulus viviparus larvae: Migration of the infective stage in agar gel. Int. J. Parasit. 1975, 5, 199-202.

Klesius PH: Immunity to Ostertagia ostertagi. Vet. Parasitol. 1988, 27, 159-167.

Michel JF, Lancaster MB, Hong C:Ostertagia ostertagi: Protective immunity in calves. Exp. Parasit. 1973, 33, 179-186.

Michel JF, Lancaster MB, Hong C: The effect of age, acquired resistance, pregnancy and lactation on some reactions of cattle to infection with Ostertagia ostertagi. Parasit. 1979, 79, 157168.

Mwegoha WM, Jørgensen RJ: Recovery of infective 3rd stage larvae of Haemonchus contortus and Ostertagia ostertagi by migration in agar gel. Acta vet. scand. 1977, 18, 293-299.

Nansen P, Steffan P, Monrad J, Grønvold J, Henriksen $S A a$ : Effects of separate and mixed grazing on trichostrongylosis in first- and second-season grazing calves. Vet. Parasit. 1990, 36, 265-276.

Ploeger HW: Effect of nematode infections on productivity of young and adult cattle on commercial dairy farms. Ph.D. Thesis. Agricultural University of Wageningen. The Netherlands. 1989.

Ross JG; Purcell DA; Dow C, Todd JR: Experimental infections of calves with Trichonstrongylus axei; the course and development of infection and lesions in low level infections. Res. vet. Sci. 1967, 8, 201-206.

\section{Sammendrag}

Udvikling af immunitet overfor Ostertagia ostertagi (Trichostrongylidae: Nematoda) hos grassende ungkvag.

Dette fors $\emptyset \mathrm{g}$ omfattede 3 grupper af kalve, $(+\mathrm{P} 2)$, (-P2) og (-P1), som alle startede deres første græsningssæson som parasitfri dyr. (+P2)- og (-P2)gruppen græssede $\mathrm{i}$ to sæsoner. I den første sæson græssede (-P2)-gruppen på en mark uden påviselige trichostrongylider ved fors $\varnothing$ gets start og dyrene blev behandlet med ormemiddel hver anden uge. Den ubehandlede $(+\mathrm{P} 2)$-gruppe græssede på en Ostertagia ostertagi inficeret mark. I den anden græsningssæson græssede disse to oprindelige grupper sammen med en ny gruppe af første-års græssende kalve (-P1) på marker inficerede med O.ostertagi.

Parasitologiske analyser viste, at (+P2)-gruppen kun havde en ubetydelig æg-udskillelse i den anden sæson, sammenlignet med grupperne (-P2) og (P1). Dette forhold peger på at æg-produktionen 
kunne være reguleret via erhvervet immunitet. Forskellen i æg-udskillelsen afspejlede sig ikke i serum pepsinogen niiveauerne, som kun var lidt forhøjede for alle grupper i den anden sæson. Post mortem undersøgelser ved fors $\emptyset$ gets afslutning viste, at kun (-P1)-gruppen havde en relativ $h ø j$ ormebyrde $i$ løben på denne tidspunkt.

Antistoffer fra 3 immunoglobulin klasser blev målt: IgA, IgG1 og IgG2. IgA og IgG1 niveauerne korrelerede med tilstedeværelsen af udviklende stadier og voksne orm i løben og niveauerne forblev for- højede i (+P2)-gruppen igennem hele eksperimentet, hvilket kunne tyde på, at disse immunglobulin klasser er involveretet $i$ et beskyttende immunsvar. I den anden sæson viste IgA og IgG1 hurtige og stejle stigninger i (-P2)-gruppen, hvilket sandsynligvis var alders-relateret og som sådan et resultat af immunsystemets modning. IgG2's rolle er uklar, idet IgG2-svaret var svagt $i$ alle grupper af kalve og vanskeligt at relatere til de parasitologiske resultater.

(Received May 22, 1992; accepted July 2, 1992).

Reprints may be requested from: J. Grønvold, Department of Veterinary Microbiology, Royal Veterinary and Agricultural University, Bülowsvej 13, DK-1870 Frederiksberg C, Denmark. 
ERRATUM to Acta vet. scand. 1992. vol. 33, no. 3. After the final proof reading a technical error has accurred. Therefore please insert the following corrected text on page 200.
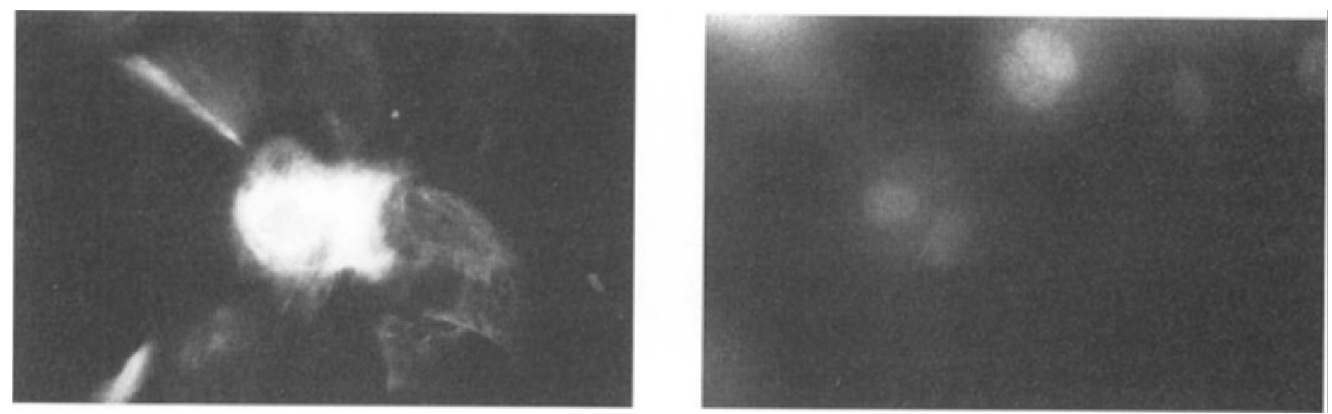

Figure 2. Presence of cytokeratine epithelial antigen in the primary cultures of bovine mammary epithelial cells. Cells stained with (A) or without (B) anticytokeratine antibody $2 \mathrm{~A} 4$.

Table 2. ODC-activity in starved MCF-7 mammary carcinoma cells stimulated with colostrum or serum.

\begin{tabular}{lcc}
\hline Treatment & ODC-activity & Relative activity \\
\hline Unstimulated & 9052 & 1,0 \\
FCS, $10 \%$ & 18650 & 2,0 \\
COL, $5 \%$ & 19412 & 2,1 \\
COL, $10 \%$ & 24660 & 2,7 \\
\hline
\end{tabular}

Starved cells ( $24 \mathrm{~h}$ in serum-free DMEM) were stimulated for $6 \mathrm{~h}$ as indicated. ODC-activity is expressed as $\mathrm{cpm} / 10^{7}$ cells $/ 60 \mathrm{~min}$. ODC=ornithine decarboxylase. $\mathrm{FCS}=$ foetal calf serum. $\mathrm{COL}=$ colostrum.

cated in malignant mammary growth (Muller et al. 1988, Slamon et al. 1987). From Fig. 1 it can be seen that the induction is dose dependent and that the inductor is not present in normal bovine milk and that it was not associated with fat. Another cell line, MCF-7, derived from mammary adenocarcinoma, responds very potently to colostrum as well (Table 2).

For the studies of the effect of colostrum in relevant cells, we established primary cultures of bovine mammary epithelium. The epithelial origin of these cultures was confirmed by demonstration of cytokeratin type intermediate filaments (Fig. 2). Colostrum stimulated DNA-synthesis in these cells very efficiently while EGF and bCOL were ineffective (Fig.3).

\section{Discussion}

Mammary secretions have been shown to contain many different growth factors (Carpenter 1980, Jaeger et al. 1987, Simmen et al. 1988, Tucker 1985). Of these EGF, in particular, has been considered to account for the majority of growth promoting activity in human milk (Carpenter 1980). We did not see EGF stimulation in our systems, however. This is hardly surprising in the case of 3T3-fibroblasts, which contain only about $10^{3}$ EGF-receptors per cell (Di Fiore et al. 1987). Unexpectedly, EGF did not promote udder epithelial cell growth either. Intactness of EGF was confirmed by its ability to induce ODC in cells known to express a high number of EGF-binding sites (not shown). Our findings do not exclude the functional significance of colostral EGF. Its physiological target could well be the offspring. EGF has been shown to play a part in cell proliferation in the gastrointestinal tract (WalkerSmith et al. 1985, Wright et al. 1990).

Other growth factors besides EGF in colostrum include insulin (Jaeger et al. 1987), IGF-1 (Simmen et al. 1988) and perhaps also serum derived peptides like platelet derived growth factor (PDGF). IGF-1 (Rinderknecht \& Humbel 1976) and PDGF (Antoniades et al. 1979) are resistant to heat. In contrast, the 